\title{
Interleukin-6 and C-reactive protein as predictors of cognitive decline in late midlife OPEN
}

Archana Singh-Manoux, $\mathrm{PhD}$

Aline Dugravot, MSc Eric Brunner, $\mathrm{PhD}$ Meena Kumari, $\mathrm{PhD}$ Martin Shipley, MSc Alexis Elbaz, MD, PhD Mika Kivimaki, PhD

Correspondence to Dr. Singh-Manoux: Archana.Singh-Manoux@inserm.fr

Editorials, pages 478 and 480

Supplemental data at Neurology.org

\section{ABSTRACT}

Objective: Peripheral inflammatory markers are elevated in patients with dementia. In order to assess their etiologic role, we examined whether interleukin-6 (IL-6) and C-reactive protein (CRP) measured in midlife predict concurrently assessed cognition and subsequent cognitive decline.

Methods: Mean value of IL-6 and CRP, assessed on 5,217 persons (27.9\% women) in 19911993 and 1997-1999 in the Whitehall II longitudinal cohort study, were categorized into tertiles to examine 10-year decline (assessments in 1997-1999, 2002-2004, and 2007-2009) in standardized scores (mean $=0, S D=1$ ) of memory, reasoning, and verbal fluency using mixed models. Mini-Mental State Examination (MMSE) was administered in 2002-2004 and 20072009; decline $\geq 3$ points was modeled with logistic regression. Analyses were adjusted for baseline age, sex, education, and ethnicity; further analyses were also adjusted for smoking, obesity, Framingham cardiovascular risk score, and chronic diseases (cancer, coronary heart disease, stroke, diabetes, and depression).

Results: In cross-sectional analysis, reasoning was 0.08 SD (95\% confidence interval [Cl] -0.14 , -0.03) lower in participants with high compared to low IL-6. In longitudinal analysis, 10-year decline in reasoning was greater (ptrend $=0.01)$ among participants with high IL-6 $(-0.35 ; 95 \%$ $\mathrm{Cl}-0.37,-0.33)$ than those with low IL-6 $(-0.29 ; 95 \% \mathrm{Cl}-0.31,-0.27)$. In addition, participants with high IL-6 had 1.81 times greater odds ratio of decline in MMSE $(95 \% \mathrm{CI} 1.20,2.71)$. CRP was not associated with decline in any test.

Conclusions: Elevated IL- 6 but not CRP in midlife predicts cognitive decline; the combined crosssectional and longitudinal effects over the 10-year observation period corresponded to an age effect of 3.9 years. Neurology ${ }^{\circledR} 2014 ; 83: 486-493$

\section{GLOSSARY}

CHD = coronary heart disease; $\mathbf{C l}=$ confidence interval; $\mathbf{C R P}=$ C-reactive protein; CVD = cardiovascular disease; IL-6 = interleukin-6; IQR = interquartile range; MMSE = Mini-Mental State Examination.

Inflammatory molecules, including acute-phase inflammatory reactants and proinflammatory cytokines, have been found in the CSF and $\beta$-amyloid plaques in patients with dementia. ${ }^{1-3}$ Inflammation appears to be a feature of dementia; amyloid deposition stimulates neuroinflammatory processes with neurotoxic effects that exacerbate neuronal damage. There is also evidence that circulating levels of inflammatory markers are raised before clinical onset of dementia; for instance, in persons without dementia, interleukin-6 (IL-6) and C-reactive protein (CRP) have been shown to predict dementia. ${ }^{4-6}$ However, given the long preclinical phase of dementia, ${ }^{7}$ it is unclear whether peripheral inflammation is a by-product of neuropathology or whether it contributes to neuronal damage.

Evidence of an association between peripheral inflammatory markers and cognitive decline rather than dementia, which represents the extreme clinical presentation of the pathologic

From INSERM (A.S.-M., A.D., A.E.), U1018, Centre for Research in Epidemiology and Population Health, Hôpital Paul Brousse, Villejuif Cedex, France; Department of Epidemiology and Public Health (A.S.-M., E.B., M. Kumari, M.S., A.E., M. Kivimaki), University College London, UK; Centre de Gérontologie (A.S.-M.), Hôpital Ste Périne, AP-HP; and University Versailles St-Quentin en Yvelines (A.D.), France.

Go to Neurology.org for full disclosures. Funding information and disclosures deemed relevant by the authors, if any, are provided at the end of the article. The Article Processing Charge was paid by the UK Medical Research Council.

This is an open access article distributed under the Creative Commons Attribution License, which permits unrestricted use, distribution, and reproduction in any medium, provided the original work is properly cited. 
process, would support an etiologic role for inflammation in cognitive aging. To date, however, few prospective studies have examined inflammatory markers in midlife as predictors of cognitive decline. Here, we examine this association using 2 markers, IL-6 and CRP, expecting IL-6 to have a stronger association with cognition as it drives the production of downstream markers such as CRP. As single measures cannot reliably separate acute and chronic inflammation and may therefore underestimate associations with disease outcomes, ${ }^{8}$ we use the mean of 2 measures taken 5 years apart to capture long-term inflammation. Our objective is to examine the association of CRP and IL- 6 in midlife and cognitive decline over 10 years in a large community-dwelling sample of men and women.

METHODS The Whitehall II study is an ongoing cohort study of men and women, originally employed by the British civil service. The target population was all London-based office staff, aged $35-55$ years. A total of 10,308 persons (6,895 men and 3,413 women), response rate $73 \%$, were recruited to the study over 1985 to $1988 .^{9}$ Since the baseline medical examination, followup examinations have taken place approximately every 5 years: 1991-1993 ( $\mathrm{n}=8,815) ; 1997-1999(\mathrm{n}=7,870) ; 2002-2004$ $(\mathrm{n}=6,967)$; and 2007-2009 ( $\mathrm{n}=6,761)$.

Standard protocol approvals, registrations, and patient consents. Ethical approval for the Whitehall II study was obtained from the University College London Medical School committee on the ethics of human research (reference number 85/0938); all participants provided written informed consent.

Assessment of IL-6 and CRP. Fasting serum was collected in 1991-1993 and 1997-1999 between 8 AM and 1 PM and stored at $-80^{\circ} \mathrm{C}$. CRP was measured with a high-sensitivity immunonephelometric assay in a BN ProSpec nephelometer (Dade Behring, Milton Keynes, UK). IL-6 was measured with a high-sensitivity ELISA (R\&D Systems, Oxford, UK). Values lower than the detection limit $(0.15 \mathrm{mg} / \mathrm{L}$ for CRP, $0.08 \mathrm{pg} / \mathrm{mL}$ for IL-6) were assigned a value equal to half the detection limit. To measure short-term biological variation and laboratory error, a repeat sample was taken from 150 participants for CRP and 241 participants for IL-6 at the 1991-1993 measure (average elapsed time between samples, 32 days $[S D=10.5$ days]). Intra-assay and interassay coefficients of variation were $4.7 \%$ and $8.3 \%$ for CRP and $7.5 \%$ and $8.9 \%$ for IL-6.

Cognitive function. The cognitive test battery, administered at 3 clinical examinations over 10 years (1997-1999, 2002-2004, and 2007-2009), was chosen to provide a comprehensive assessment of cognitive function and be appropriate for this population composed of individuals younger than in most studies on cognitive aging. ${ }^{10}$ The tests included in the analysis had high test-retest reliability, range $0.60-0.89$, assessed on 556 participants who were invited back to the clinic within 3 months of having taken the test in 1997-1999.

Short-term verbal memory was assessed with a 20 -word free recall test. Participants were presented a list of 201 - or 2-syllable words at 2-second intervals and were then asked to recall in writing as many of the words as possible in any order with 2 minutes to do so.

The Alice Heim 4-I is composed of a series of 65 verbal and mathematical reasoning items of increasing difficulty. ${ }^{11}$ It tests inductive reasoning, measuring the ability to identify patterns and infer principles and rules. Participants had 10 minutes to do this section.

We used 2 measures of verbal fluency, phonemic and semantic, combined for the purposes of the analysis. ${ }^{12}$ Participants were asked to recall in writing as many words beginning with $S$ (phonemic fluency) and as many animal names (semantic fluency) as they could. One minute was allowed for each test; the observed range on these tests was $0-35$.

The Mini-Mental State Examination (MMSE), ${ }^{13}$ a brief 30-point measure of global cognitive function, was administered at the last 2 waves of the cognitive data collection.

Covariates. Covariates included age, sex, ethnicity (white, south Asian, black, other), and education, the highest qualification on leaving full-time education (lower secondary school or less, higher secondary school [usually achieved at age 18], university or higher degree). Smoking status was reported by participants and classified as never, ex, or current smoker. Obesity was defined as body mass index $\geq 30 \mathrm{~kg} / \mathrm{m}^{2}{ }^{14}$ The Framingham general cardiovascular disease (CVD) risk score was used to assess subclinical disease, calculated using data on age, highdensity lipoprotein cholesterol, total cholesterol, systolic blood pressure, cigarette smoking, and diabetes. ${ }^{15}$

The chronic diseases considered as covariates were coronary heart disease (CHD); stroke, identified using hospital records database; cancer, using the National Health Service cancer registry; and diabetes, determined by oral glucose tolerance test (fasting glucose $\geq 7.0 \mathrm{mmol} / \mathrm{L}$, 2-hour postload glucose $\geq 11.1 \mathrm{mmol} / \mathrm{L}$ ), reported doctor-diagnosed diabetes, or use of diabetes medication. ${ }^{16}$ Antidepressant use was assessed using questions on medication. All participants were followed for mortality using linkage to the national mortality database.

Statistical analysis. All analyses were conducted using STATA 12. Participant characteristics were described as percentages or mean (SD) when appropriate. Inflammatory markers were categorized into tertiles using mean values from 1991-1993 to 1997-1999. We also ran analyses using continuous scores, modeled as an increment of $1 \mathrm{SD}$, after log transforming the inflammatory measures owing to skewed distributions. The association of inflammatory markers with mortality over the follow-up was examined using Cox proportional hazards models.

In order to allow comparison across cognitive tests, we standardized the raw scores of each test to $z$ scores (mean $=0$; $\mathrm{SD}=1$ ). In the longitudinal analysis, the standardization to the $z$ score was carried out using the mean and SD from 1997 to 1999. Linear mixed models ${ }^{17}$ were used to estimate the cross-sectional and longitudinal association of inflammatory markers with cognition (3 assessments, 1997-1999, 2002-2004, 2007-2009). Mixed models use all available data over the follow-up, take into account the fact that repeated measures on the same individual are correlated with each other, and can handle missing data. In these analyses, both the intercept and the slope were fitted as random effects, allowing individuals to have different cognitive scores at baseline and different rates of cognitive decline over the follow-up. The intercept in these models yields the cross-sectional association and the slope an estimate of the 10-year decline in cognitive scores and the associated $95 \%$ confidence interval (CI). These analyses were adjusted for sociodemographic characteristics (age, sex, ethnicity, and education). In a further step, analyses were additionally 
adjusted for covariates associated with higher levels of inflammatory markers (smoking, obesity, Framingham CVD risk, CHD, stroke, cancer, diabetes, and antidepressant use).

The interaction term between sex, time, and inflammatory markers suggested similar cognitive decline in men and women (all $p$ between 0.11 and 0.41 ), leading us to combine men and women in the analysis. For both the baseline and the longitudinal analysis, we tested for a linear trend as a function of tertiles of the inflammatory markers. To allow interpretation of the regression estimates of top vs bottom tertile of the inflammatory marker, we compared them with the effect of age on cognition. The regression estimates were divided by the effect of 1 year increase in age on cognition; the latter was calculated by regressing the standardized 1997-1999 cognitive score on age.

In further analyses, we examined the association of the inflammatory markers (mean value of measures taken in 19911993 and 1997-1999) and decline in MMSE between 20022004 and 2007-2009, modeled as a decline of 3 points or more. These analyses were undertaken using logistic regression as the distribution was highly skewed and unsuitable for linear regression. We compared the C-statistics of 2 predictive models for decline in MMSE, one containing age and sex only and the other additionally containing the inflammatory marker to assess its incremental discriminative ability.

In sensitivity analyses, we used a Bonferroni-corrected critical $p$ value of $0.0125(0.05 / 4)$ based on the fact that 4 cognitive tests were used in the analysis (memory, reasoning, fluency, MMSE).

RESULTS A total of 7,666 (74.4\%) of the original 10,308 participants of the Whitehall II study participated in 1991-1993 and 1997-1999 waves of data collection, when inflammatory markers were assessed. Those with CRP values $\geq 10 \mathrm{mg} / \mathrm{L}$ ( $\mathrm{n}=$ 159 in $1991-1993$ and $n=197$ in 1997-1999), an indicator of acute infection, were removed from the analysis. A total of 5,316 had valid data at both waves, allowing mean values of IL- 6 and CRP to be calculated (figure). A total of 212 deaths were recorded over the cognitive follow-up and 1 SD higher CRP (1.25, 95\% CI $1.07,1.47)$ and IL-6 $(1.27,95 \%$ CI 1.11, 1.45) were associated with greater hazard ratio of mortality. Subsequent analyses were undertaken on 5,217 participants with cognitive data over the follow-up. Approximately $72 \%$ had cognitive data at all 3 waves and $18 \%$ at 2 waves. Compared to individuals not included in these analyses, the analytic samples consisted of younger participants (55.7 vs 56.4 years, $p<0.001)$, more men $(72.1 \%$ vs $61.6 \%, p<0.001)$, and more educated individuals ( $30.4 \%$ vs $23.8 \%$ had a university degree, $p<0.001$ ).

The median for IL-6 was $1.43 \mathrm{pg} / \mathrm{mL}$ (interquartile range $[\mathrm{IQR}] 1.07,1.99)$, based on assessments in $1991-1993(1.41 \mathrm{pg} / \mathrm{mL})$ and 1997-1999 (1.42 pg/ $\mathrm{mL}$, correlation $r=0.47)$; the corresponding median was $0.98 \mathrm{mg} / \mathrm{L}$ for CRP (IQR 0.52, 1.94, first and second assessments $0.89 \mathrm{mg} / \mathrm{mL}$ and $1.02 \mathrm{mg} / \mathrm{L}$,

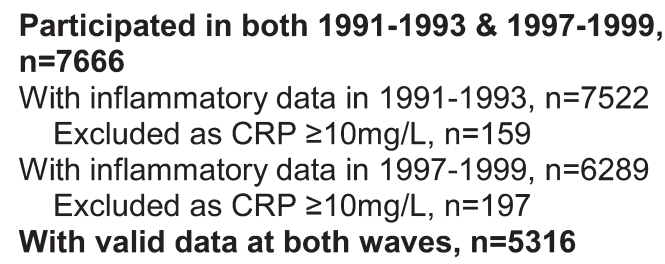

Participated in both 1991-1993 \& 1997-1999, $\mathrm{n}=7666$

With inflammatory data in 1991-1993, n=7522

Excluded as CRP $\geq 10 \mathrm{mg} / \mathrm{L}, \mathrm{n}=159$

With inflammatory data in 1997-1999, $\mathrm{n}=6289$

Excluded as CRP $\geq 10 \mathrm{mg} / \mathrm{L}, \mathrm{n}=197$

With valid data at both waves, $n=5316$

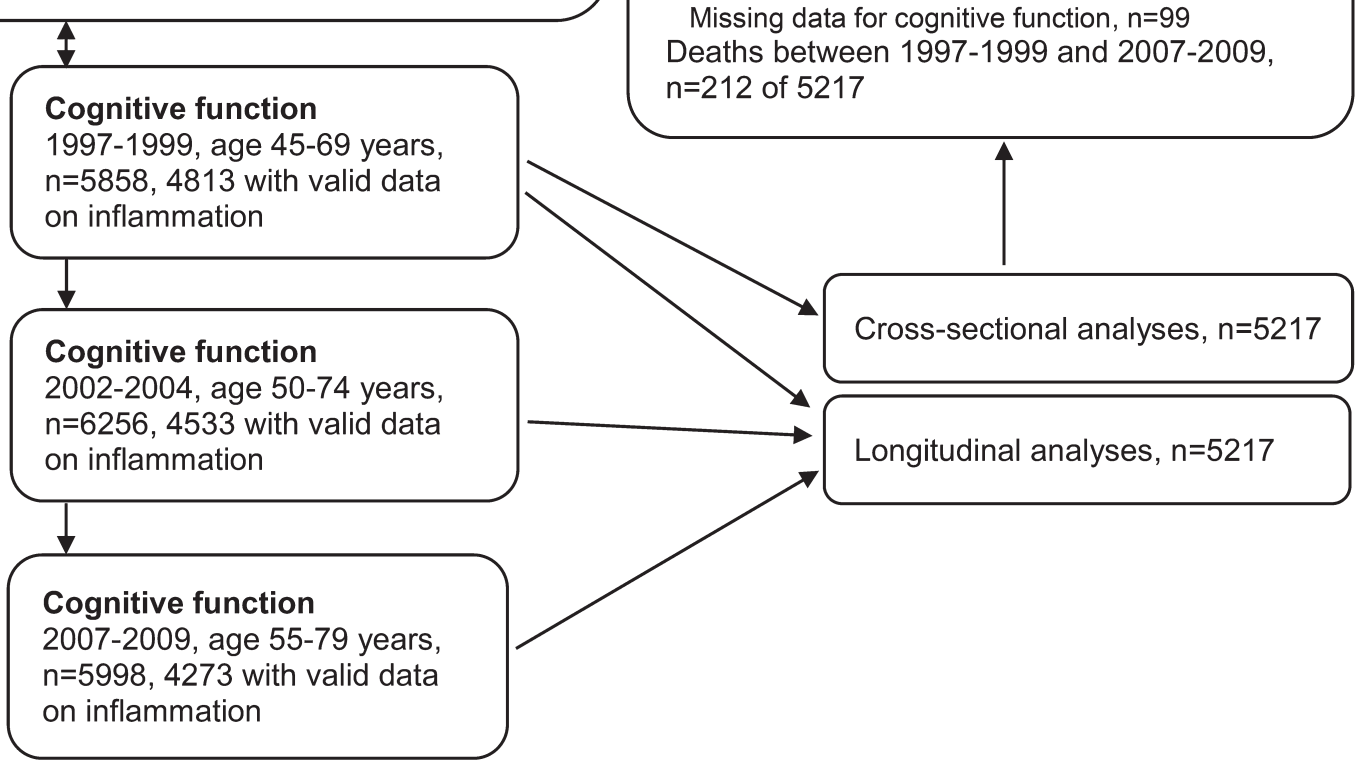

Excluded, $n=2449$

Lack of inflammation data in 1991-93, $n=144$

Lack of two measures of inflammation, $n=2206$

Missing data for cognitive function, $n=99$

Deaths between 1997-1999 and 2007-2009, $\mathrm{n}=212$ of 5217

Cognitive function 1997-1999, age 45-69 years, $\mathrm{n}=5858,4813$ with valid data on inflammation

Cognitive function 2002-2004, age 50-74 years, $\mathrm{n}=6256,4533$ with valid data

Cognitive function 2007-2009, age 55-79 years, 政 on inflammation

$\mathrm{CRP}=\mathrm{C}$-reactive protein. 
respectively, correlation $r=0.61$ ). Changes in inflammatory marker levels between the 2 assessments were not associated with cognitive tests (all $r \leq 0.03$ ), leading us not to examine them further. The inflammatory markers, averaged over 2 assessments, were moderately correlated with each other $\left(r_{\mathrm{s}}=0.49, p<0.001\right)$. One year greater age was associated with $-0.040 \mathrm{SD}$ lower memory, -0.036 lower reasoning, and -0.043 lower verbal fluency, all $p<0.0001$. Table 1 presents sample characteristics as a function of the tertiles of IL- 6 and CRP. Both markers were associated with all baseline covariates, except stroke; CRP was also not associated with cancer.

In cross-sectional analyses (table 2), adjusted for sociodemographic measures, those in the highest IL-6 tertile had poorer cognitive scores on all tests, the difference compared to those in the lowest tertile ranging from -0.08 to -0.13 of an $S D$ - corresponding to an age effect of 2.0 years for memory, 2.2 years for reasoning, and 3.0 years for verbal fluency. Those in the intermediate and high tertile of CRP had lower scores in reasoning $(-0.09$; $95 \% \mathrm{CI}-0.14,-0.04)$. Adjustment for the full set of covariates (table e-1 on the Neurology ${ }^{\circledR}$ Web site at Neurology.org) attenuated associations with memory but higher IL-6 remained associated with poorer scores on reasoning and fluency and higher CRP levels with poorer scores on reasoning.

In longitudinal analyses, a decline over 10 years of approximately one-third of a baseline SD was observed on all tests (table 3). Compared to the lowest IL-6 tertile $(-0.29,95 \%$ CI -0.31 , $-0.27)$, those in the intermediate $(-0.32,95 \% \mathrm{CI}$ $-0.35,-0.30 ; p<0.05)$ and highest $(-0.35,95 \%$ CI $-0.37,-0.33, p<0.001)$ tertiles experienced faster decline in reasoning. The difference in decline in reasoning between the highest and lowest IL-6 tertile corresponded to an age effect of 1.7 years. The decline in the highest tertile remained statistically significant when adjusted for the full range of covariates (table e-2). CRP in the highest tertile was also associated with faster decline in reasoning (table 3) but adjustment for all covariates rendered the difference nonsignificant (table e-2).

Table 4 shows the association of the inflammatory markers with decline of $\geq 3$ points $(n=191,4.7 \%)$ in MMSE scores between 2002-2004 and 2007-2009. Those in the highest IL-6 tertile were 1.85 (95\% CI $1.25,2.73)$ times more likely to register decline in MMSE than those in the lowest tertile. This greater likelihood of decline in the highest IL-6 category remained in the fully adjusted model (odds ratio 1.81; 95\% CI 1.20, 2.71; model 6). The associations of CRP with decline in MMSE did not reach statistical significance. The change in C-statistics suggested that IL-6 (from 0.666 to $0.684, p=0.05$ ) but not CRP (from 0.666 to $0.671, p=0.32$ ) improves discriminative ability in prediction of decline in MMSE.

The cross-sectional and longitudinal associations between IL-6 and reasoning (tables 2-4) remained statistically significant after Bonferroni correction

\begin{tabular}{|c|c|c|c|c|c|c|c|c|}
\hline \multirow[t]{3}{*}{ Table 1} & -1999) correlat & es of IL- 6 and CRP & & & & & & \\
\hline & \multicolumn{4}{|l|}{ IL-6 (tertile) ${ }^{\mathrm{a}}$} & \multicolumn{4}{|l|}{ CRP (tertile) ${ }^{a}$} \\
\hline & $\begin{array}{l}\text { Low } \\
(<1.18 \mathrm{pg} / \mathrm{mL})\end{array}$ & $\begin{array}{l}\text { Intermediate } \\
(1.18-1.75 \mathrm{pg} / \mathrm{mL})\end{array}$ & $\begin{array}{l}\text { High } \\
\text { ( } \geq 1.75 \mathrm{pg} / \mathrm{mL})\end{array}$ & $p^{b}$ & $\begin{array}{l}\text { Low } \\
\text { (<0.65 mg/L) }\end{array}$ & $\begin{array}{l}\text { Intermediate } \\
(0.65-1.48 \mathrm{mg} / \mathrm{L})\end{array}$ & $\begin{array}{l}\text { High } \\
\text { ( } 11.48 \mathrm{mg} / \mathrm{L})\end{array}$ & $p^{b}$ \\
\hline N & 1,729 & 1,742 & 1,746 & & 1,737 & 1,739 & 1,741 & \\
\hline Age, $y$, mean (SD) & $54.0(5.6)$ & $55.9(6.0)$ & $57.2(6.1)$ & $<0.001$ & $54.8(5.9)$ & $55.8(6.0)$ & $56.5(6.2)$ & $<0.001$ \\
\hline Male, \% & 75.0 & 73.2 & 68.2 & $<0.001$ & 74.5 & 74.4 & 67.4 & $<0.001$ \\
\hline High education, \% & 36.2 & 29.7 & 24.2 & $<0.001$ & 35.5 & 28.6 & 26.0 & $<0.001$ \\
\hline White, \% & 95.8 & 92.7 & 87.3 & $<0.001$ & 93.9 & 92.3 & 89.5 & $<0.001$ \\
\hline Current smoker, \% & 5.3 & 8.5 & 13.6 & $<0.001$ & 5.8 & 8.0 & 13.7 & $<0.001$ \\
\hline Obesity, ${ }^{c} \%$ & 4.3 & 10.9 & 22.9 & $<0.001$ & 3.1 & 11.0 & 24.0 & $<0.001$ \\
\hline Antidepressants, \% & 2.7 & 2.5 & 3.3 & 0.02 & 2.1 & 2.8 & 3.6 & $<0.001$ \\
\hline $\begin{array}{l}\text { Framingham CVD risk, } \\
\text { mean (SD) }\end{array}$ & $9.2(6.2)$ & $12.1(8.2)$ & $14.8(10.2)$ & $<0.001$ & $9.7(6.8)$ & 12.1 (8.2) & $14.3(10.0)$ & $<0.001$ \\
\hline Coronary heart disease, $\%$ & 3.9 & 5.7 & 8.3 & $<0.001$ & 3.3 & 6.3 & 8.3 & $<0.001$ \\
\hline Stroke, \% & 0.4 & 0.3 & 0.6 & 0.37 & 0.5 & 0.4 & 0.4 & 0.87 \\
\hline Diabetes, \% & 2.5 & 4.6 & 7.6 & $<0.001$ & 2.4 & 4.5 & 7.9 & $<0.001$ \\
\hline Cancer, \% & 2.2 & 3.3 & 4.1 & 0.01 & 3.2 & 2.8 & 3.8 & 0.27 \\
\hline
\end{tabular}

Abbreviations: CRP = C-reactive protein; CVD = cardiovascular disease; IL- 6 = interleukin-6.

a Tertiles based on average of measures taken in 1991-1993 and 1997-1999.

${ }^{\mathrm{b}} \mathrm{p}$ for trend.

${ }^{\mathrm{c} U s i n g}$ World Health Organization recommendations. 
Table 2 Cross-sectional association between IL-6 and CRP (mean of measures in 1991-1993 and 1997-1999) and cognitive function (1997-1999)

\begin{tabular}{|c|c|c|c|c|c|c|c|}
\hline Inflammatory markers & $\mathrm{N}$ & Memory, $\beta$ (95\% Cl) & $p$ & $\begin{array}{l}\text { Reasoning (AH4-I), } \\
\beta(95 \% \mathrm{CI})\end{array}$ & $p$ & $\begin{array}{l}\text { Verbal fluency, }{ }^{a} \\
\beta(95 \% \mathrm{CI})\end{array}$ & p \\
\hline \multicolumn{8}{|l|}{ IL-6, pg/mL (tertile) } \\
\hline$<1.18$ & 1,729 & 0.00 (Ref) & & 0.00 (Ref) & & 0.00 (Ref) & \\
\hline $1.18-1.74$ & 1,724 & $-0.05(-0.11,0.01)$ & 0.12 & $-0.01(-0.07,0.04)$ & 0.59 & $0.01(-0.04,0.07)$ & 0.65 \\
\hline$\geq 1.75$ & 1,746 & $-0.08(-0.14,-0.01)^{\mathrm{c}}$ & 0.016 & $-0.08(-0.14,-0.03)^{d}$ & 0.002 & $-0.13(-0.19,-0.07)^{e}$ & $<0.0001$ \\
\hline$p$ for trend & & 0.01 & & 0.002 & & $<0.001$ & \\
\hline $\begin{array}{l}\text { Log-transformed IL-6 } \\
\text { (per } 1 \text { SD increment) }\end{array}$ & 5,217 & $-0.03(-0.05,-0.00)^{\mathrm{c}}$ & 0.028 & $-0.03(-0.06,-0.01)^{d}$ & 0.002 & $-0.04(-0.06,-0.01)^{d}$ & 0.002 \\
\hline \multicolumn{8}{|l|}{ CRP, mg/L (tertile) ${ }^{b}$} \\
\hline$<0.65$ & 1,737 & 0.00 (Ref) & & 0.00 (Ref) & & 0.00 (Ref) & \\
\hline $0.65-1.47$ & 1,739 & $-0.04(-0.10,0.02)$ & 0.17 & $-0.09(-0.14,-0.04)^{\mathrm{e}}$ & $<0.0001$ & $-0.04(-0.10,0.01)$ & 0.13 \\
\hline$\geq 1.48$ & 1,741 & $-0.05(-0.11,0.01)$ & 0.11 & $-0.09(-0.14,-0.04)^{e}$ & 0.001 & $-0.05(-0.11,0.00)$ & 0.09 \\
\hline$p$ for trend & & 0.10 & & $<0.001$ & & 0.09 & \\
\hline $\begin{array}{l}\text { Log-transformed CRP } \\
\text { (per } 1 \text { SD increment) }\end{array}$ & 5,217 & $-0.03(-0.05,-0.00)^{\mathrm{c}}$ & 0.035 & $-0.03(-0.05,-0.01)^{d}$ & 0.008 & $-0.02(-0.04,0.00)$ & 0.12 \\
\hline
\end{tabular}

Abbreviations: AH4-I = Alice Heim 4-I; Cl = confidence interval; CRP = C-reactive protein; IL-6 = interleukin-6; Ref = reference.

Regression coefficients ( $\beta$ and 95\% Cls) estimates from linear mixed models that assess cross-sectional and longitudinal associations simultaneously. Analysis adjusted for age, sex, ethnicity, and education.

${ }^{a}$ Composed of a test of semantic (animal words) and phonemic (S words) fluency.

${ }^{\mathrm{b}}$ Tertiles based on average of measures taken in 1991-1993 and 1997-1999.

${ }^{\mathrm{c}} p<0.05$.

${ }^{d} p<0.01$.

${ }^{\mathrm{e}} \mathrm{p}<0.001$

for 4 tests; this was also the case for IL-6 and decline in MMSE.

DISCUSSION Our results, based on participants aged 56 years at the start of cognitive testing, suggest that inflammatory markers are associated with cognition, in both cross-sectional and longitudinal associations. Three features qualify these findings. First, memory had no strong association with the inflammatory markers. Second, of the 2 markers examined, IL-6 had a more robust association with cognition. Third, although the cross-sectional effects were stronger, the longitudinal effects were nevertheless present, suggesting that midlife inflammation is related to cognitive decline. The effects may appear small but over the 10-year observation period the combined effect using both cross-sectional and longitudinal effects corresponds to an age effect of 3.9 years for reasoning.

Previous studies on the association between inflammation and cognitive decline are inconsistent. Some studies show no association ${ }^{18-20}$ and others show greater decline in those with higher inflammation. ${ }^{21-24}$ However, much of the evidence is based on older adults, where preclinical dementia cannot be ruled out. No previous study to our knowledge has used repeated measures of inflammatory markers to correct for within-person fluctuations in inflammatory markers in analysis with cognitive outcomes. Memory appears not to be one of the domains affected by long-term inflammation in our analysis. Previous cross-sectional studies report associations with multiple cognitive domain $s^{25}$; the longitudinal studies used either a global measure, such as the MMSE, ${ }^{21}$ or combined tests to produce global scores. ${ }^{24}$ All the tests used in the present analyses have been shown previously to be sensitive to age-related changes in cognition in midlife. ${ }^{10}$ Timed tests of reasoning, such as the Alice Heim test, are good measures of processing speed or mental efficiency. ${ }^{26}$ Further support for the lack of association with memory comes from studies showing greater effects of inflammatory factors on vascular rather than Alzheimer-type dementia. ${ }^{6,27}$

Previous studies on the association between inflammatory markers and cognitive outcomes have not been conclusive on the specific marker that may be of special interest. In the Rotterdam Study, IL-6 but not CRP was associated with an increased risk of dementia. ${ }^{4}$ In relation to cognition, some studies report associations with CRP but not IL- $6,{ }^{28}$ others with IL-6 but not CRP, ${ }^{23}$ and some find both to be associated with cognition. ${ }^{12}$ However, neuroimaging studies show consistently stronger associations with IL-6 than with CRP. ${ }^{29-31}$ IL-6 is a major proinflammatory cytokine, produced in a variety of tissues, and CRP is a downstream product of the acute phase response, derived via IL-6-dependent hepatic 
Table 3 Association between IL-6 and CRP (mean of measures in 1991-1993 and 1997-1999) and cognitive decline (1997-1999, 20022004, 2007-2009)

\begin{tabular}{|c|c|c|c|c|c|c|c|}
\hline Inflammatory markers & $\mathbf{N}$ & Memory, $\beta$ (95\% Cl) & p & $\begin{array}{l}\text { Reasoning (AH4-I), } \\
\beta(95 \% \mathrm{Cl})\end{array}$ & p & $\begin{array}{l}\text { Verbal fluency, } \\
\beta(95 \% \mathrm{Cl})\end{array}$ & $p$ \\
\hline \multicolumn{8}{|l|}{ IL-6, pg/mL (tertile) } \\
\hline $1.18-1.74$ & 1,724 & $-0.27(-0.31,-0.23)$ & 0.26 & $-0.32(-0.35,-0.30)^{\mathrm{c}}$ & 0.047 & $-0.39(-0.42,-0.36)$ & 0.71 \\
\hline$\geq 1.75$ & 1,746 & $-0.30(-0.34,-0.25)$ & 0.96 & $-0.35(-0.37,-0.33)^{d}$ & 0.001 & $-0.37(-0.40,-0.33)$ & 0.48 \\
\hline $\begin{array}{l}\text { Log-transformed IL-6 } \\
\text { (per } 1 \text { SD increment) }\end{array}$ & 5,217 & $-0.01(-0.03,0.01)$ & 0.44 & $-0.02(-0.03,-0.00)^{c}$ & 0.037 & $-0.00(-0.02,0.02)$ & 0.83 \\
\hline \multicolumn{8}{|l|}{ CRP, mg/L (tertile) ${ }^{b}$} \\
\hline$<0.65$ & 1,737 & $-0.28(-0.32,-0.24)$ & & $-0.32(-0.34,-0.29)$ & & $-0.36(-0.39,-0.33)$ & \\
\hline $0.65-1.47$ & 1,739 & $-0.29(-0.33,-0.24)$ & 0.84 & $-0.30(-0.32,-0.27)$ & 0.25 & $-0.38(-0.41,-0.35)$ & 0.49 \\
\hline
\end{tabular}

Abbreviations: AH4-I = Alice Heim 4-I; Cl = confidence interval; CRP = C-reactive protein; IL-6 = interleukin-6.

Regression coefficients ( $\beta$ and 95\% Cls) estimates from linear mixed models that assess cross-sectional and longitudinal associations simultaneously.

Analysis adjusted for age, sex, ethnicity, and education.

${ }^{a}$ Composed of a test of semantic (animal words) and phonemic (S words) fluency.

${ }^{b}$ Tertiles based on average of measures taken in 1991-1993 and 1997-1999.

${ }^{\mathrm{c}} \mathrm{p}<0.05$.

${ }^{d} p<0.001$.

biosynthesis and secretion into the systemic circulation. ${ }^{32}$ Thus, IL-6 might be a more sensitive and appropriate marker for a study of inflammation and cognition.
Brains of patients with dementia have activated microglia, inflammatory factors, and high circulating inflammatory markers. However, at least one previous study suggests that reverse causation is an unlikely

\begin{tabular}{|c|c|c|c|c|c|c|}
\hline $\begin{array}{l}\text { Associat } \\
(2002-2\end{array}$ & $\begin{array}{l}\text { between IL-6 and } \\
4,2007-2009)\end{array}$ & RP (mean of meas & s in 1991-1993 & d 1997-1999) anc & lecline of 3 points & more in MMSE \\
\hline Inflammatory markers & $\begin{array}{l}\text { Model 1, } \\
\text { OR }(95 \% \mathrm{Cl})\end{array}$ & $\begin{array}{l}\text { Model 2, } \\
\text { OR (95\% Cl) }\end{array}$ & $\begin{array}{l}\text { Model 3, } \\
\text { OR }(95 \% \mathrm{Cl})\end{array}$ & $\begin{array}{l}\text { Model 4, } \\
\text { OR }(95 \% \text { CI) }\end{array}$ & $\begin{array}{l}\text { Model 5, } \\
\text { OR (95\% Cl) }\end{array}$ & $\begin{array}{l}\text { Model 6, } \\
\text { OR }(95 \% \mathrm{Cl})\end{array}$ \\
\hline \multicolumn{7}{|l|}{ IL-6, pg/mL (tertile) ${ }^{\mathrm{a}}$} \\
\hline$<1.18$ & 1.00 (Ref) & 1.00 (Ref) & 1.00 (Ref) & 1.00 (Ref) & 1.00 (Ref) & 1.00 (Ref) \\
\hline $1.18-1.74$ & $1.26(0.83,1.90)$ & $1.25(0.83,1.88)$ & $1.28(0.85,1.94)$ & $1.22(0.81,1.85)$ & $1.26(0.83,1.89)$ & $1.24(0.82,1.88)$ \\
\hline$\geq 1.75$ & $1.85(1.25,2.73)^{b}$ & $1.80(1.21,2.66)^{b}$ & $1.96(1.31,2.91)^{c}$ & $1.73(1.16,2.58)^{b}$ & $1.83(1.23,2.71)^{b}$ & $1.81(1.20,2.71)^{\mathrm{b}}$ \\
\hline$p$ for trend & 0.001 & 0.002 & 0.001 & 0.005 & 0.002 & 0.003 \\
\hline \multicolumn{7}{|l|}{ CRP, mg/L (tertile) $)^{a}$} \\
\hline$<0.65$ & 1.00 (Ref) & 1.00 (Ref) & 1.00 (Ref) & 1.00 (Ref) & 1.00 (Ref) & 1.00 (Ref) \\
\hline $0.65-1.47$ & $1.19(0.81,1.73)$ & $1.18(0.81,1.72)$ & $1.21(0.83,1.77)$ & $1.14(0.78,1.67)$ & $1.18(0.81,1.73)$ & $1.17(0.79,1.71)$ \\
\hline$\geq 1.48$ & $1.34(0.92,1.95)$ & $1.30(0.89,1.89)$ & $1.40(0.96,2.06)$ & $1.23(0.83,1.80)$ & $1.32(0.91,1.92)$ & $1.26(0.85,1.87)$ \\
\hline$p$ for trend & 0.12 & 0.18 & 0.08 & 0.30 & 0.15 & 0.25 \\
\hline
\end{tabular}

Abbreviations: $\mathrm{Cl}=$ confidence interval; CRP = C-reactive protein; IL-6 = interleukin-6; MMSE = Mini-Mental State Examination; OR = odds ratio; Ref $=$ reference.

Model 1: analysis adjusted for age, sex, ethnicity, and education; model 2: model 1 + smoking; model 3: model 1 + obesity; model 4: model 1 + Framingham cardiovascular disease risk score; model 5: model 1 + coronary heart disease, stroke, cancer, diabetes, antidepressant use; model 6: all covariates. Total $n=4,057$, decline in MMSE score $\geq 3$ points: $n=191$.

a Tertiles based on average of measures taken in 1991-1993 and 1997-1999.

${ }^{\mathrm{b}} \mathrm{p}<0.01$.

${ }^{c} p<0.001$. 
explanation of the association between peripheral inflammatory markers and dementia. CRP was assessed in the Honolulu Aging Study 25 years prior to the assessment of dementia and those with higher levels of CRP had greater risk of dementia. ${ }^{33}$ Elevated levels of peripheral inflammatory markers are not simply a consequence of dementia-related processes; infection, trauma, ischemia, or accumulation of lipids can trigger inflammatory responses. ${ }^{34}$ Inflammatory markers might influence cognition through their prothrombotic effects ${ }^{35}$; they are thought to be involved in atherothrombotic vascular events as suggested by their association with silent brain infarction. ${ }^{36}$

Our findings need to be considered in light of study strengths and limitations. A key strength of the study is the use of 2 measures of each inflammatory marker taken 5 years apart, prior to cognitive testing in order to better account for within-person variability and measurement error. The age range of the participants (45-69 at the start of cognitive testing) is a strength as the results are unlikely to be minimally if at all affected by preclinical dementia. A further strength is the use of appropriate statistical methodology to model change. Many studies ${ }^{21,23,24}$ showing inflammatory markers to predict cognitive decline adjusted inappropriately for the baseline cognitive score.

Limitations of our study include the lack of socioeconomic and ethnic diversity in the population; all participants were in stable employment at study inception, thus were not fully representative of the general population. A further limitation is the use of only 2 serologic markers of systemic inflammation. Although CRP and IL- 6 are widely measured, it remains unclear whether there are more relevant markers of peripheral inflammation in relation to $\operatorname{cog}$ nitive function. Finally, the categorization of the inflammatory markers and decline in MMSE is arbitrary and further research is needed to find clinically relevant cutoffs in nonelderly populations.

Taken together, although much recent effort has been directed at understanding the role of abnormal amyloid metabolism for dementia, multiple factors are likely to be involved in cognitive aging. Inflammation is likely to play a role because of its impact on cerebral small-vessel disease, which could lead to changes that affect cognitive ageing. ${ }^{37}$ The use of nonsteroidal anti-inflammatory drugs (naproxen or celecoxib) in the Alzheimer's Disease Anti-Inflammatory Prevention Trial was found not to improve cognitive function in older adults ${ }^{38}$ but recent reanalysis of those data suggests a beneficial role of antiinflammatory drugs in the early, asymptomatic phases of the dementia. ${ }^{39}$ The finding of elevations in proinflammatory cytokine production during early middle age in persons with a family history of Alzheimer disease $^{40}$ also suggests a role for inflammation in cognition. Our findings do not establish causality but suggest that peripheral inflammation in midlife might influence cognitive aging.

\section{AUTHOR CONTRIBUTIONS}

A.S.-M. formulated the research question, supervised the analysis, and wrote first and successive drafts of the paper. A.D. undertook the statistical analyses and commented on drafts. E.B., M. Kumari, M.S., A.E., and M. Kivimaki interpreted the results and commented on drafts.

\section{ACKNOWLEDGMENT}

The authors thank all the participating civil service departments and their welfare, personnel, and establishment officers; the British Occupational Health and Safety Agency; the British Council of Civil Service Unions; all participating civil servants in the Whitehall II study; and all members of the Whitehall II study team. The Whitehall II study team comprises research scientists, statisticians, study coordinators, nurses, data managers, administrative assistants, and data entry staff.

\section{STUDY FUNDING}

US NIH (R01AG013196 to A.S.-M.; R01AG034454 to A.S.-M. and M. Kivimaki, R01HL036310 to M. Kivimaki), the UK Medical Research Council (K013351 to M. Kivimaki), the Economic and Social Research Council (to M. Kivimaki), and the British Heart Foundation (to E.B.).

\section{DISCLOSURE}

A. Singh-Manoux receives research support from the US NIH (R01AG013196; R01AG034454). A. Dugravot reports no disclosures relevant to the manuscript. E. Brunner receives research support from the British Heart Foundation. M. Kumari receives support from the Economic and Social Research Council and NIH. M. Shipley and A. Elbaz report no disclosures relevant to the manuscript. M. Kivimaki receives research support from US NIH (R01AG034454, R01HL036310), the UK Medical Research Council (K013351), and the Economic and Social Research Council. Go to Neurology.org for full disclosures.

Received November 8, 2013. Accepted in final form March 10, 2014.

\section{REFERENCES}

1. Duong T, Nikolaeva M, Acton PJ. C-reactive protein-like immunoreactivity in the neurofibrillary tangles of Alzheimer's disease. Brain Res 1997;749:152-156.

2. Iwamoto N, Nishiyama E, Ohwada J, Arai H. Demonstration of CRP immunoreactivity in brains of Alzheimer's disease: immunohistochemical study using formic acid pretreatment of tissue sections. Neurosci Lett 1994;177: 23-26.

3. Gorelick PB. Role of inflammation in cognitive impairment: results of observational epidemiological studies and clinical trials. Ann NY Acad Sci 2010;1207:155-162.

4. Engelhart MJ, Geerlings MI, Meijer J, et al. Inflammatory proteins in plasma and the risk of dementia: the Rotterdam Study. Arch Neurol 2004;61:668-672.

5. Tan ZS, Beiser AS, Vasan RS, et al. Inflammatory markers and the risk of Alzheimer disease: the Framingham Study. Neurology 2007;68:1902-1908.

6. Sundelof J, Kilander L, Helmersson J, et al. Systemic inflammation and the risk of Alzheimer's disease and dementia: a prospective population-based study. J Alzheimers Dis 2009; 18:79-87.

7. Jack CR Jr, Knopman DS, Jagust WJ, et al. Hypothetical model of dynamic biomarkers of the Alzheimer's pathological cascade. Lancet Neurol 2010;9:119-128.

8. Danesh J, Kaptoge S, Mann AG, et al. Long-term interleukin-6 levels and subsequent risk of coronary heart 
disease: two new prospective studies and a systematic review. PLoS Med 2008;5:e78.

9. Marmot M, Brunner E. Cohort profile: the Whitehall II study. Int J Epidemiol 2005;34:251-256.

10. Singh-Manoux A, Kivimaki M, Glymour MM, et al. Timing of onset of cognitive decline: results from Whitehall II prospective cohort study. BMJ 2012;344:d7622.

11. Heim AW. AH 4 Group Test of General Intelligence. Windsor, UK: NFER-Nelson Publishing Company Ltd.; 1970 .

12. Borkowski JG, Benton AL, Spreen O. Word fluency and brain damage. Neuropsychologica 1967;5:135-140.

13. Folstein MF, Folstein SE, McHugh PR. "Mini-mental state": a practical method for grading the cognitive state of patients for the clinician. J Psychiatr Res 1975;12:189-198.

14. WHO. Obesity: preventing and managing the global epidemic: report of a WHO consultation. World Health Organ Tech Rep Ser 2000;894:i-253.

15. D’Agostino RB Sr, Vasan RS, Pencina MJ, et al. General cardiovascular risk profile for use in primary care: the Framingham Heart Study. Circulation 2008;117:743-753.

16. Alberti KG, Zimmet PZ. Definition, diagnosis and classification of diabetes mellitus and its complications: part 1: diagnosis and classification of diabetes mellitus provisional report of a WHO consultation. Diabet Med 1998;15: 539-553.

17. Laird NM, Ware JH. Random-effects models for longitudinal data. Biometrics 1982;38:963-974.

18. Dik MG, Jonker C, Hack CE, Smit JH, Comijs HC, Eikelenboom P. Serum inflammatory proteins and cognitive decline in older persons. Neurology 2005;64:1371-1377.

19. Alley DE, Crimmins EM, Karlamangla A, Hu P, Seeman TE. Inflammation and rate of cognitive change in high-functioning older adults. J Gerontol A Biol Sci Med Sci 2008;63:50-55.

20. Weuve J, Ridker PM, Cook NR, Buring JE, Grodstein F. High-sensitivity C-reactive protein and cognitive function in older women. Epidemiology 2006;17:183-189.

21. Yaffe K, Lindquist K, Penninx BW, et al. Inflammatory markers and cognition in well-functioning African-American and white elders. Neurology 2003;61:76-80.

22. Wilson CJ, Cohen HJ, Pieper CF. Cross-linked fibrin degradation products (D-dimer), plasma cytokines, and cognitive decline in community-dwelling elderly persons. J Am Geriatr Soc 2003;51:1374-1381.

23. Rafnsson SB, Deary IJ, Smith FB, et al. Cognitive decline and markers of inflammation and hemostasis: the Edinburgh Artery Study. J Am Geriatr Soc 2007;55:700-707.

24. Weaver JD, Huang MH, Albert M, Harris T, Rowe JW, Seeman TE. Interleukin-6 and risk of cognitive decline: MacArthur studies of successful aging. Neurology 2002; 59:371-378.

25. Noble JM, Manly JJ, Schupf N, Tang MX, Mayeux R, Luchsinger JA. Association of C-reactive protein with cognitive impairment. Arch Neurol 2010;67:87-92.
26. Salthouse TA. The processing-speed theory of adult age differences in cognition. Psychol Rev 1996;103:403-428.

27. Schmidt R, Schmidt H, Curb JD, Masaki K, White LR, Launer LJ. Early inflammation and dementia: a 25-year follow-up of the Honolulu-Asia Aging Study. Ann Neurol 2002;52:168-174.

28. Teunissen CE, van Boxtel MP, Bosma H, et al. Inflammation markers in relation to cognition in a healthy aging population. J Neuroimmunol 2003;134:142-150.

29. Jefferson AL, Massaro JM, Wolf PA, et al. Inflammatory biomarkers are associated with total brain volume: the Framingham Heart Study. Neurology 2007;68: 1032-1038.

30. Satizabal CL, Zhu YC, Mazoyer B, Dufouil C, Tzourio C. Circulating IL-6 and CRP are associated with MRI findings in the elderly: the 3C-Dijon Study. Neurology 2012; 78:720-727.

31. Fornage M, Chiang YA, O'Meara ES, et al. Biomarkers of inflammation and MRI-defined small vessel disease of the brain: the Cardiovascular Health Study. Stroke 2008;39: 1952-1959.

32. Rattazzi M, Puato M, Faggin E, Bertipaglia B, Zambon A, Pauletto P. C-reactive protein and interleukin- 6 in vascular disease: culprits or passive bystanders? J Hypertens 2003; 21:1787-1803.

33. Schmidt R, Schmidt H, Curb JD, Masaki K, White LR, Launer LJ. Early inflammation and dementia: a 25-year follow-up of the Honolulu-Asia Aging Study. Ann Neurol 2002;52:168-174.

34. Sullivan GW, Sarembock IJ, Linden J. The role of inflammation in vascular diseases. J Leukoc Biol 2000;67: 591-602.

35. Ross R. Atherosclerosis: an inflammatory disease. N Engl J Med 1999;340:115-126.

36. Hoshi T, Kitagawa K, Yamagami H, Furukado S, Hougaku H, Hori M. Relations of serum high-sensitivity C-reactive protein and interleukin-6 levels with silent brain infarction. Stroke 2005;36:768-772.

37. Marchesi VT. Alzheimer's dementia begins as a disease of small blood vessels, damaged by oxidative-induced inflammation and dysregulated amyloid metabolism: implications for early detection and therapy. FASEB J 2011;25: 5-13.

38. Martin BK, Szekely C, Brandt J, et al. Cognitive function over time in the Alzheimer's Disease Anti-inflammatory Prevention Trial (ADAPT): results of a randomized, controlled trial of naproxen and celecoxib. Arch Neurol 2008; 65:896-905.

39. Breitner JC, Baker LD, Montine TJ, et al. Extended results of the Alzheimer's disease anti-inflammatory prevention trial. Alzheimers Dement 2011;7:402-411.

40. van EE, Eikelenboom P, Comijs H, et al. Vascular factors and markers of inflammation in offspring with a parental history of late-onset Alzheimer disease. Arch Gen Psychiatry 2009;66:1263-1270. 


\section{Neurology}

\section{Interleukin-6 and C-reactive protein as predictors of cognitive decline in late midlife}

Archana Singh-Manoux, Aline Dugravot, Eric Brunner, et al.

Neurology 2014;83;486-493 Published Online before print July 2, 2014

DOI 10.1212/WNL.0000000000000665

\section{This information is current as of July 2, 2014}

\section{Updated Information \& Services \\ Supplementary Material}

References

Citations

Subspecialty Collections

Permissions \& Licensing

Reprints including high resolution figures, can be found at:

http://n.neurology.org/content/83/6/486.full

Supplementary material can be found at:

http://n.neurology.org/content/suppl/2014/07/02/WNL.0000000000000 665.DC1

http://n.neurology.org/content/suppl/2014/07/02/WNL.0000000000000 665.DC2

This article cites 39 articles, 10 of which you can access for free at: http://n.neurology.org/content/83/6/486.full\#ref-list-1

This article has been cited by 8 HighWire-hosted articles: http://n.neurology.org/content/83/6/486.full\#\#otherarticles

This article, along with others on similar topics, appears in the following collection(s):

All Cognitive Disorders/Dementia

http://n.neurology.org/cgi/collection/all_cognitive_disorders_dementia Cognitive aging

http://n.neurology.org/cgi/collection/cognitive_aging

Risk factors in epidemiology

http://n.neurology.org/cgi/collection/risk_factors_in_epidemiology

Information about reproducing this article in parts (figures,tables) or in its entirety can be found online at:

http://www.neurology.org/about/about_the_journal\#permissions

Information about ordering reprints can be found online:

http://n.neurology.org/subscribers/advertise

Neurology ${ }^{\circledR}$ is the official journal of the American Academy of Neurology. Published continuously since 1951, it is now a weekly with 48 issues per year. Copyright (O 2014 American Academy of Neurology. All rights reserved. Print ISSN: 0028-3878. Online ISSN: 1526-632X.

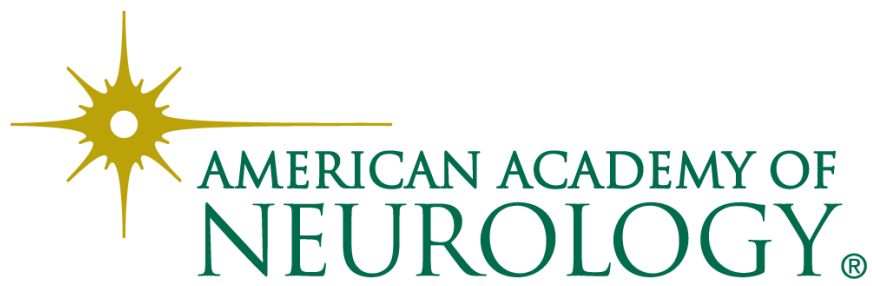

